\section{電解精製浴からの銅電析初期の表面形態および 結晶組織に及ぼす添加剂の相乗効果 *}

\title{
Synergistic Effect of Additives on Morphology and Texture of Copper Deposited at Initial Stage from Electrorefining Solution
}

\author{
by Hiroaki NAKANO ${ }^{\mathrm{a}}$, Satoshi OUE ${ }^{\mathrm{b}}$, Tomoaki NISHINO ${ }^{\mathrm{c}}$, \\ Hisaaki FUKUSHIMA $^{\mathrm{d}}$ and Shigeo KOBAYASHI ${ }^{\mathrm{e}}$
}

\begin{abstract}
a. Professor, Faculty of Engineering, Kyushu University, 744, Motooka, Nishi-ku, Fukuoka 8190395 Japan (Corresponding author E-mail: nakano@zaiko.kyushu-u.ac.jp)

b. Assistant Professor, Faculty of Engineering, Kyushu University

c. Post Graduate Student, Graduate School of Engineering, Kyushu University, Now, SENJU METAL INDUSTRY CO., LTD.

d. Professor Emeritus, Faculty of Engineering, Kyushu University

e. Associate Professor, Faculty of Engineering, Kyushu Sangyo University, 2-3-1, Matsukadai, Higashi-ku, Fukuoka 813-8503 Japan
\end{abstract}

\begin{abstract}
Electrodeposition of $\mathrm{Cu}$ was conducted in a synthetic electrorefining solution to investigate the effect of gelatin, thiourea and chloride ions on the polarization curve for $\mathrm{Cu}$ deposition, morphology, texture, surface roughness and the throwing power of the deposited $\mathrm{Cu}$. In a solution containing both gelatin and chloride ions, the cathode potential for $\mathrm{Cu}$ deposition was significantly polarized at current densities above $200 \mathrm{~A} / \mathrm{m}^{2}$, while the thiourea depolarized the potential for $\mathrm{Cu}$ deposition at 200 to $1000 \mathrm{~A} / \mathrm{m}^{2}$. In a solution containing the three additives, i.e. gelatin, thiourea and chloride ions, the potential for $\mathrm{Cu}$ deposition was polarized at $500 \mathrm{~A} / \mathrm{m}^{2}$. It is supposed that the synergistic effect of gelatin and chloride ions on the polarization prevailed over the depolarization effect of thiourea. In the $\mathrm{Cu}$ deposited at initial stage, the chloride ions promoted the field-oriented texture with the orientation of $\langle 110\rangle$ direction. However, $\mathrm{Cu}$ deposited at initial stage from the solution containing gelatin, thiourea and chloride ions was composed of both the inclined texture type and the epitaxial growth type of crystals. The surface roughness and throwing power of the deposited $\mathrm{Cu}$ was most improved in the solution containing gelatin, thiourea and chloride ions, showing the synergistic effect of three additives. The thiourea had an effect on decreasing the surface roughness of the deposited $\mathrm{Cu}$, and chloride ions improved the throwing power of $\mathrm{Cu}$.
\end{abstract}

KEY WORDS: Copper, Electrorefining, Gelatin, Thiourea, Chloride Ions, Morphology

\section{1. 緒言}

$\mathrm{Cu}$ の電解精製においては，陰極表面を平滑にするとともに不 純物の共析を抑制するため, 電解液にゼラチン ${ }^{1-3)}$, チオ尿素が 電解液に添加され，また陽極からのスライムの形成を容易にする ため塩化物イオンも加えられる。電解液にゼラチン, チオ尿素, 塩化物イオンを添加すると, 陰極電位が卑に移行し, 電析物の結 晶粒が細かくなる。著者らは, これまでに $\mathrm{Cu}$ の電解精製におけ るゼラチン，ポリエチレングリコールといった高分子添加剤の影

*2012 年 6 月 1 日受付 2012 年 7 月 11 日受理

1. 正会員 九州大学大学院 工学研究院 材料工学部門教授

2. 正会員 九州大学大学院 工学研究院 材料工学部門 助教

3. 九州大学大学院学生 (現: 千住金属工業株式会社)

4. 正会員 九州大学大学院 工学研究院 材料工学部門名誉教授

5. 正会員九州産業大学工学部物質生命化学科准教授

[ 著者連絡先 ] FAX: 092-802-2990

nakano@zaiko.kyushu-u.ac.jp

キーワード : 銅, 電解精製, チオ尿素, ゼラチン, 塩化物イオン, 形態
響 ${ }^{4)}$, チオ尿素の影響 ${ }^{5)}$, 高分子添加剤と塩化物イオンの相乗 効果 ${ }^{6)}$ について報告した。また, 電解精製の実操業をシミュレー トした条件下において, 長時間の連続電解を行い, 電析 $\mathrm{Cu}$ の表 面形態と結晶組織に及ぼすゼラチン, チオ尿素, 塩化物イオンの 相乗効果について報告した ${ }^{7)}$ 。その中で塩化物イオンは, 電析 $\mathrm{Cu}$ を< $110>$ 方位をとって成長させる作用があり, 共存するゼラ チン, チオ尿素は $<110>$ 方位の電場配向繊維型の組織を維持す る効果があることを示した ${ }^{7) 。 ~}$

しかし, 電析 $\mathrm{Cu}$ の表面形態, 結晶組織に及ぼすゼラチン, チ オ尿素, 塩化物イオンの相乗作用についてはまだ不明な点が多い。 そこで本研究では, $\mathrm{Cu}$ 電析の分極曲線および電析初期の $\mathrm{Cu}$ (膜 厚: 約 $18 \mu \mathrm{m})$ の表面形態, 結晶組織, 表面粗度, 均一電着性に 及ぼす添加剤の相乗効果について調査した。

\section{2. 実 験 方 法}

$\mathrm{Cu}$ 電解精製の基本液組成は $\mathrm{CuSO}_{4} \cdot 5 \mathrm{H}_{2} \mathrm{O} 0.708 \mathrm{~mol} / \mathrm{L}, \mathrm{H}_{2} \mathrm{SO}_{4}$ 


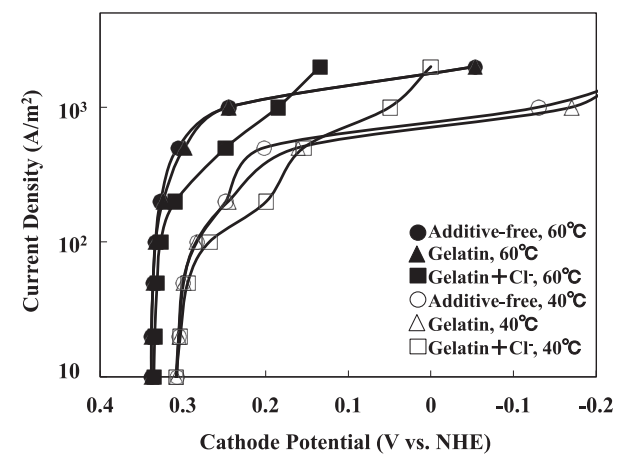

Fig.1 Polarization curves for $\mathrm{Cu}$ deposition in the electrorefining solutions containing gelatin and $\mathrm{Cl}^{-}$ions.

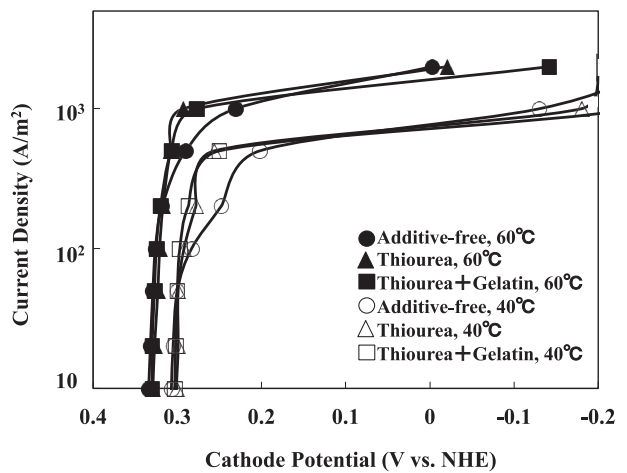

Fig.2 Polarization curves for $\mathrm{Cu}$ deposition in the electrorefining solutions containing thiourea and gelatin.

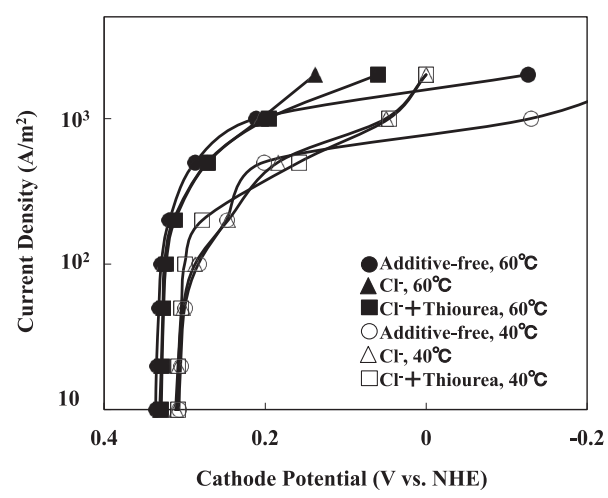

Fig.3 Polarization curves for $\mathrm{Cu}$ deposition in the electrorefining solutions containing $\mathrm{Cl}^{-}$ions and thiourea.

想され，高分子添加剂は， $\mathrm{Cu}^{+}$の吸着中間体 $\mathrm{CuCl}_{\mathrm{ad}}$ から金属 $\mathrm{Cu}$ への還元反応を抑制することが交流インピーダンス法による解析 結果から実証されている ${ }^{6)}$ 。本研究のゼラチンを極微量含む溶 液においても, 塩化物イオンが共存すると, 従来より報告されて いる $\mathrm{Cu}$ 電析の分極に対する高分子添加剤と塩化物イオンの相乗 効果が認められた。 $40^{\circ} \mathrm{C}$ の溶液では $60^{\circ} \mathrm{C}$ の溶液に比べ, 電位が 全体的に卑に移行しているが， $60^{\circ} \mathrm{C}$ の場合と同様に $\mathrm{Cu}$ 電析に対 するゼラチン, 塩化物イオンの相乗効果が $200 \mathrm{~A} / \mathrm{m}^{2}$ 周辺で見ら れた。

Fig. 2 に $\mathrm{Cu}$ 電析の分極曲線に及ぼすチ才尿素, ゼラチン添加 の影響を示す。 $60^{\circ} \mathrm{C}$ の溶液では, $500 \sim 1000 \mathrm{~A} / \mathrm{m}^{2}$ の電流密度域で, また $40^{\circ} \mathrm{C}$ の溶液では, $200 \sim 500 \mathrm{~A} / \mathrm{m}^{2}$ の電流密度域でチ才尿素 を添加することにより $\mathrm{Cu}$ の電析電位が復極した。ゼラチンが共 存してもチオ尿素による復極効果がそのまま残存した。チオ尿素 $\left[\mathrm{SC}\left(\mathrm{NH}_{2}\right)_{2}\right]$ は，溶液中で分解して HS- になり易い $\left.{ }^{8}\right) 。$ 。陰極にイ オンが吸着すると Helmholtz 二重層が形成されるが，これが HS のようなアニオンの特異吸着の場合は, 内部 Helmholtz 面の電位 が低下し, その結果カソード反応の過電圧が減少 ( 反応速度定数 の増大 ) することが Helmholtz 二重層の電位分布モデルにより報 告されている ${ }^{8,9)}$ 。本研究において, チ才尿素の添加により $\mathrm{Cu}$ の電析電位が復極した一因としては, $\mathrm{HS}^{-}$の特異吸着による内部 Helmholtz 面の電位低下の効果が考えられる。

Fig. 3 に $\mathrm{Cu}$ 電析の分極曲線に及ぼす塩化物イオン, チオ尿素 添加の影響を示す。 $40^{\circ} \mathrm{C}, 60^{\circ} \mathrm{C}$ の溶液共に, 塩化物イオンのみ を添加しても $\mathrm{Cu}$ 電析の分極曲線はほとんど変化しなかった。チ オ尿素が共存しても $60^{\circ} \mathrm{C}$ の溶液では, 分極曲線は塩化物イオン のみを添加した場合とほぼ同様であり, Fig. 2 に示寸チオ尿素に 


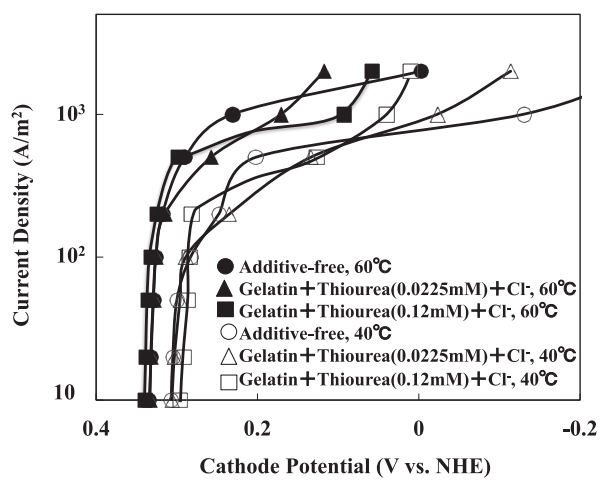

Fig.4 Polarization curves for $\mathrm{Cu}$ deposition in the electrorefining solutions containing gelatin, thiourea and $\mathrm{Cl}^{-}$ions.
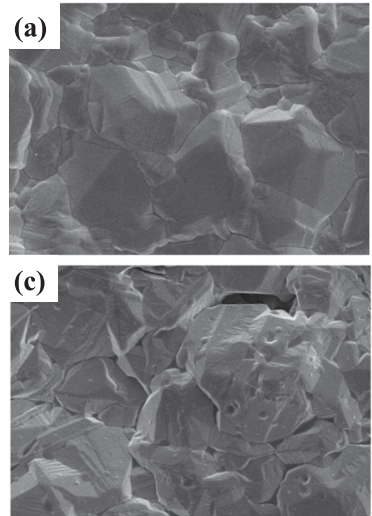

(a) additive-free (b) Gelatin
(c) $\mathrm{Cl}^{-}$
(d) Thiourea
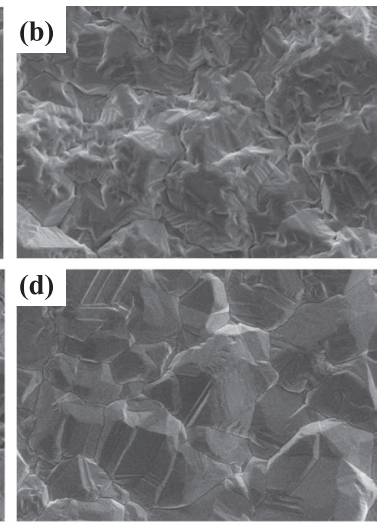

$5 \mu \mathrm{m}$

Fig.5 SEM images of $\mathrm{Cu}$ deposited for $42 \mathrm{~min}$ at $200 \mathrm{~A} / \mathrm{m}^{2}$ from an additive-free solution or solution containing one additive.

よる復極効果は特に認められなかった。その原因としては, 塩 化物イオンを含む溶液では, $\mathrm{Cl}^{-}$の特異吸着または $\mathrm{Cu}^{+}$の中間体 $\mathrm{CuCl}_{\mathrm{ad}}$ の吸着により, チ才尿素の吸着が抑制されている可能性 がある。ただし, $40^{\circ} \mathrm{C}$ の溶液では, $200 \mathrm{~A} / \mathrm{m}^{2}$ の電流密度で, 塩化 物イオンが共存してもチオ尿素による復極効果が認められた。

Fig. 4 に $\mathrm{Cu}$ 電析の分極曲線に及ぼすゼラチン, 塩化物イオン, チ才尿素添加の影響を示す。 $60^{\circ} \mathrm{C}$ の場合, $200 \mathrm{~A} / \mathrm{m}^{2}$ 以下の電流密 度域では 3 種の添加剤を含む溶液と添加剤無しの溶液で分極曲線 にほとんど差が見られないが， $500 \mathrm{~A} / \mathrm{m}^{2}$ の電流密度では 3 種の添 加剂 ( チ才尿素 $0.0225 \mathrm{mmol} / \mathrm{L}$ ) を含む溶液で分極が認められた。 $500 \mathrm{~A} / \mathrm{m}^{2}$ ではチ才尿素には復極効果があるが (Fig. 2), ゼラチン と塩化物イオンには, 分極の相乗効果 (Fig. 1) があり, その分極 の相乗効果の方が勝り, 3 種の添加剂 ( チオ尿素 $0.0225 \mathrm{mmol} / \mathrm{L}$ ) を含む溶液では分極したと考えられる。しかし，チ才尿素の濃 度を $0.12 \mathrm{mmol} / \mathrm{L}$ と高くすると, チ才尿素の復極効果が大きくな り, $500 \mathrm{~A} / \mathrm{m}^{2}$ でも 3 種の添加剤を含む溶液と添加剤無しの溶液で 電位に差がなくなった。一方, $40^{\circ} \mathrm{C}$ の溶液では, チ才尿素の濃度 を $0.12 \mathrm{mmol} / \mathrm{L}$ と高くすると, チ才尿素の復極効果が大きく 3 種 の添加剤を含む溶液でも $200 \mathrm{~A} / \mathrm{m}^{2}$ では電位が貴な方に移行した。 しかし, 電流密度が $500 \mathrm{~A} / \mathrm{m}^{2}$ と高くなるとチ才尿素の濃度に関 わらず，3 種の添加剤を含む溶液では分極効果が見られた。

Fig. 1 〜 において各種添加剂の効果に及ぼす液温の影響に着 目すると, $\mathrm{Cu}$ 電析の分極に対するゼラチン単独の効果あるいは ゼラチンと塩化物イオンの相乗効果は, $40^{\circ} \mathrm{C}$ と $60^{\circ} \mathrm{C}$ ではほぼ同 等であった。しかし, チ才尿素による復極効果は, $200 \mathrm{~A} / \mathrm{m}^{2}$ では
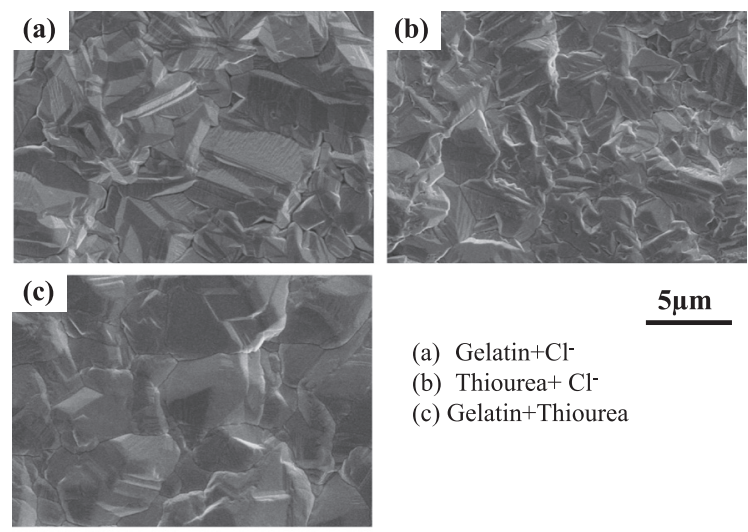

$5 \mu \mathrm{m}$

(a) Gelatin $+\mathrm{Cl}^{-}$

(b) Thiourea $+\mathrm{Cl}^{-}$

(c) Gelatin+Thiourea

Fig.6 SEM images of $\mathrm{Cu}$ deposited for $42 \mathrm{~min}$ at $200 \mathrm{~A} / \mathrm{m}^{2}$ from a solution containing two additives.
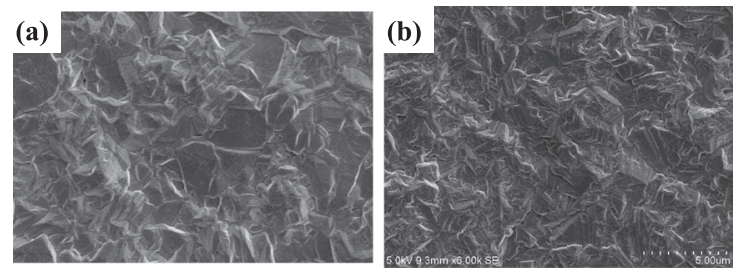

(a) Gelatin + Thiourea $(0.0225 \mathrm{mM})+\mathrm{Cl}$

(b) Gelatin + Thiourea $(0.12 \mathrm{mM})+\mathrm{Cl}^{-}$

$5 \mu \mathrm{m}$

Fig.7 SEM images of $\mathrm{Cu}$ deposited for $42 \mathrm{~min}$ at $200 \mathrm{~A} / \mathrm{m}^{2}$ from a solution containing three additives.

明らかに $40^{\circ} \mathrm{C}$ 方が $60^{\circ} \mathrm{C}$ よりさくなった。 $\mathrm{HS}^{-}$の特異吸着が $40^{\circ} \mathrm{C}$ 方が $60^{\circ} \mathrm{C} よ り$ 生じ易いことが推察される。

\section{$3 \cdot 2$ 電析 Cu の形態, 組織に及ぼす添加剂の影響}

Fig. 5 に添加剤無しまたは 1 種類の添加剤を含む $60^{\circ} \mathrm{C}$ の溶液に て $200 \mathrm{~A} / \mathrm{m}^{2}, 42$ 分間の電解を行い得られた電析 $\mathrm{Cu}$ の表面 SEM 像を示す。添加剤無しの溶液 (a) から得られた電析物には, 3 $5 \mu \mathrm{m}$ 程度の塊状の結晶が見られた。ゼラチンを添加すると (b) 塊 状の結晶が小さくなり, 小さい板状の結晶が積層した形態となっ た。塩化物イオンを添加すると (c) 添加剂無しの場合と同様に 3 $\sim 5 \mu \mathrm{m}$ 程度の塊状の結晶となったが，塊状結晶と塊状結晶の境 界に隙間が見られた。チ才尿素を添加した溶液 (d) から得られた 電析物は板状結晶が積層した塊状となり, 平滑な面が多数認めら れた。

Fig. 6 に 2 種類の添加剤を含む溶液から電析させた $\mathrm{Cu}$ の表面 SEM 像を示寸。ゼラチンと塩化物イオンが共存した溶液 (a)では, 板状結晶が積層した塊状となり, 塊状結晶と塊状結晶の境界に若 干隙間が見られた。チオ尿素と塩化物イオンが共存した場合 (b)， 不規則な小さい板状結晶が積層した形態を示した。また塩化物イ オンのみを添加した場合 [Fig. 5 (c) ] に認められた塊状結晶と塊状 結晶の境界の隙間はほとんど見られなくなった。ゼラチンとチオ 尿素を含む溶液では (c), 平滑な面から成る塊状の結晶を示し, チ才尿素のみを添加した場合 [Fig. 5 (d) ] と類似の形態となった。

Fig. 7 に 3 種類の添加剂を含む溶液から電析させた $\mathrm{Cu}$ の表面 SEM 像を示す。ゼラチン, チオ尿素, 塩化物イオンの 3 種類の 添加剂を含む溶液から得られた電析 $\mathrm{Cu}$ は, 結晶粒が微細となり, 且つ平滑な面を示した。チオ尿素の濃度を $0.12 \mathrm{mmol} / \mathrm{L}$ と高くす ると (b)，結晶粒はより微細となった。

電析させた銅の断面をEBSD 法により解析した。Fig. 8 に添 加剂無しまたは 1 種類の添加剤を含む溶液から得られた $\mathrm{Cu}$ の EBSD による結晶方位解析像を示す。以下 Fig. $8 \sim 10$ に示寸結 

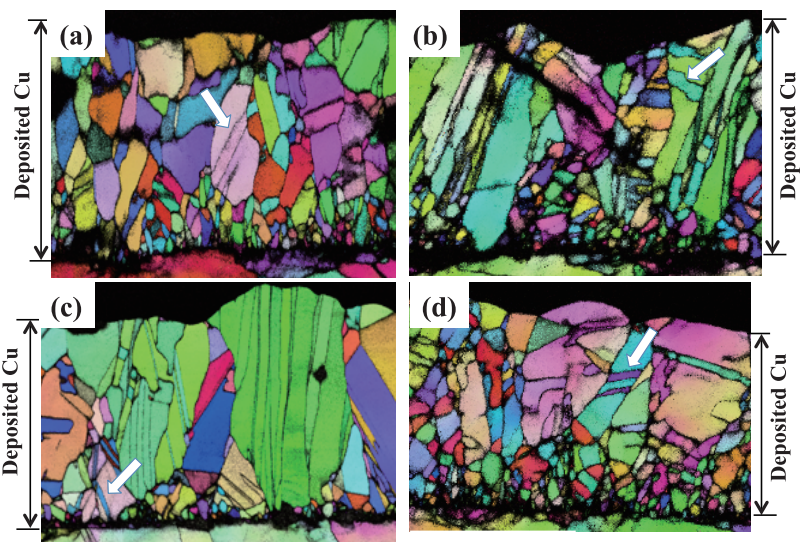

(a) additive-free (b) Gelatin

$\begin{array}{ll}\text { (c) } \mathrm{Cl}^{-} & \text {(d) Thiourea }\end{array}$

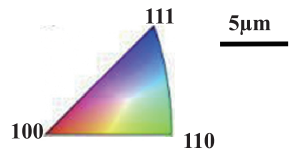

Fig.8 Crystal orientation mapping images of reference direction with respect to the cross section of $\mathrm{Cu}$ deposited for $42 \mathrm{~min}$ at $200 \mathrm{~A} / \mathrm{m}^{2}$ from an additivefree solution or solution containing one additive.
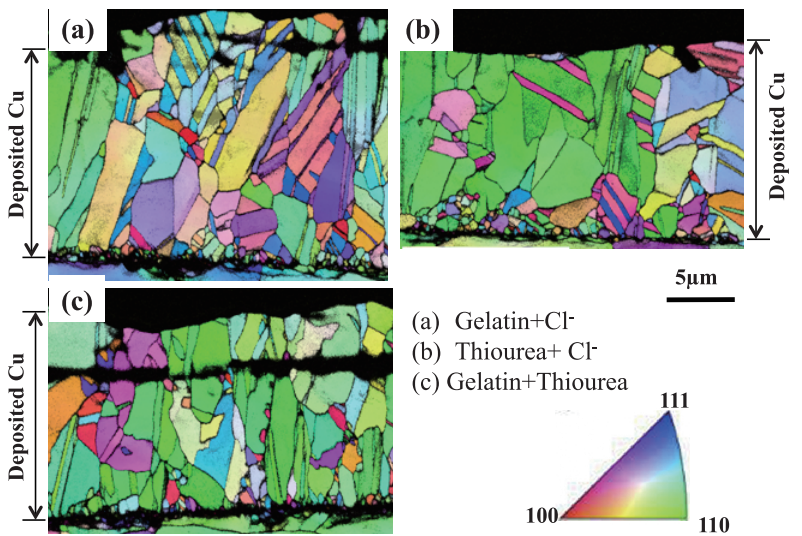

(a) Gelatin $+\mathrm{Cl}$

(b) Thiourea $+\mathrm{Cl}^{-}$

(c) Gelatin+Thiourea

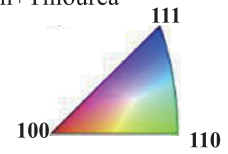

Fig.9 Crystal orientation mapping images of reference direction with respect to the cross section of $\mathrm{Cu}$ deposited for $42 \mathrm{~min}$ at $200 \mathrm{~A} / \mathrm{m}^{2}$ from a solution containing two additives.

晶方位解析像は, 電析銅表面の法線方向と一致する Reference direction (RD) に変換したものである。添加剤無しの溶液では (a), 電析初期は無配向分散状の微細な結晶粒となったが, $3 \sim 5 \mu \mathrm{m}$ 以上の膜厚で結晶粒が大きくなり, 直下の結晶粒の結晶方位を引 き継いだエピタキシャル成長に移行した。ゼラチンを添加する (b) と電析初期は無配向分散状の微細な結晶粒となっているが, 途 中から傾斜した $<110>$ 配向の繊維状の結晶とエピタキシャル成 長している結晶の両者が混在していた。塩化物イオンを添加し た場合 (c) は, 基板面近傍から $<110>$ 配向の電場配向繊維型とな る箇所と, エピタキシャル成長している箇所の双方が見られた。 $260 \mathrm{~A} / \mathrm{m}^{2}, 48$ 時間の電解において, 塩化物イオンは, 電析 $\mathrm{Cu}$ を $<110>$ 一優先配向させ, 繊維状の組織にする作用のある事が報告 されている ${ }^{7)}$ 。本研究では, 塩化物イオンは, ほぼ電析初期か ら<110>配向の電場配向繊維型にする効果があることが分かっ た。チオ尿素を添加した溶液 (d) では, 電析初期は無配向分散状 の微細な結晶となり, 途中からエピタキシャル成長に移行してお り, 添加剤無しの溶液 (a) と類似の傾向を示した。ただし, 添加 剂無しの場合に比べ結晶粒が若干小さくなった。また, 添加剤無 しまたは 1 種類の添加剤を含む溶液から得られた何れの試料 [ (a) 〜 (d) ] においても一部の箇所で双晶 (Fig. 8 の図中白矢印で示寸)
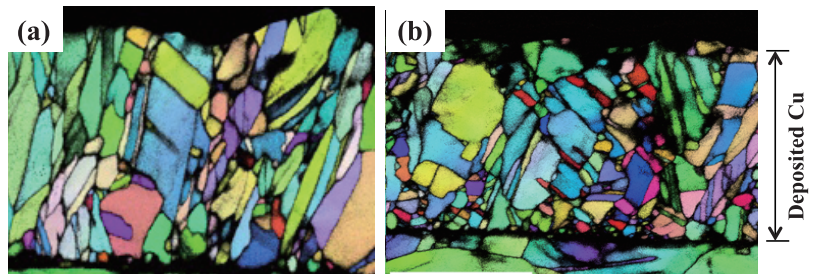

(a) Gelatin + Thiourea $(0.0225 \mathrm{mM})+\mathrm{Cl}^{-}$

(b) Gelatin + Thiourea $(0.12 \mathrm{mM})+\mathrm{Cl}^{-}$

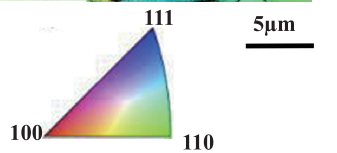

Fig.10 Crystal orientation mapping images of reference direction with respect to the cross section of $\mathrm{Cu}$ deposited for $42 \mathrm{~min}$ at $200 \mathrm{~A} / \mathrm{m}^{2}$ from a solution containing three additives.

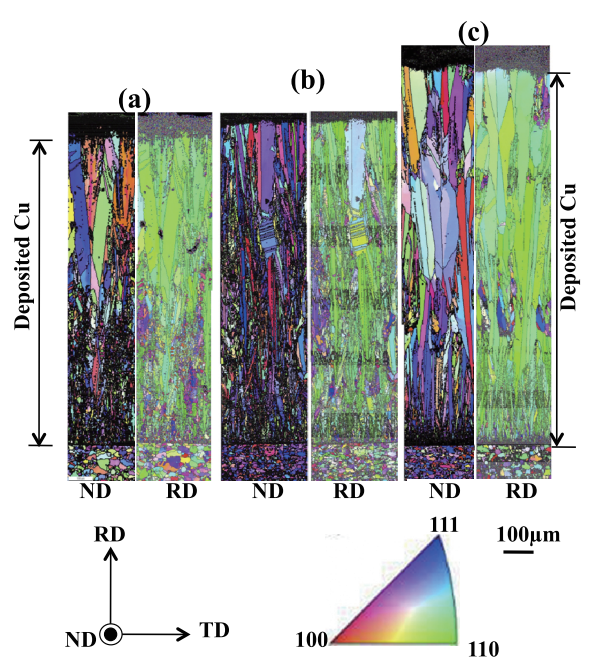

Fig.11 Crystal orientation mapping images of the cross section of $\mathrm{Cu}$ deposited for 48 hours at $260 \mathrm{~A} / \mathrm{m}^{2}$ from solution containing three additives. [ (a) glue $(1.71 \mathrm{mg} / \mathrm{L})+$ thiourea $(0.0225 \mathrm{mM})+\mathrm{Cl}^{-}(0.61 \mathrm{mM}),(\mathrm{b})$ glue $(1.71$ $\mathrm{mg} / \mathrm{L})+$ thiourea $(0.0225 \mathrm{mM})+\mathrm{Cl}^{-}(1.65 \mathrm{mM})$, (c) glue $(1.71 \mathrm{mg} / \mathrm{L})+$ thiourea $\left.(0.225 \mathrm{mM})+\mathrm{Cl}^{-}(1.65 \mathrm{mM})\right]$

が観察された。

2 種類の添加剂を含む溶液から得られた $\mathrm{Cu} の$ EBSD による結 晶方位解析像を Fig. 9 に示す。ゼラチンと塩化物イオンを添加す る (a) といろいろな方向に傾斜した繊維状の結晶が見られた。ま た表面近傍には, 多数の双晶が観察された。チ才尿素と塩化物イ オンを含む溶液 (b) では, < $110>$ 配向の幅の広い電場配向繊維型 となった。また電析初期から表面にかけて多数の双晶が観察され た。ゼラチンとチオ尿素を添加した場合 (c)，＜110>配向の電場 配向繊維型とエピタキシャル成長型が混在した結晶となった。

ゼラチン, チオ尿素, 塩化物イオンの 3 種類の添加剤を含む溶 液から得られた $\mathrm{Cu}$ の EBSD による結晶方位解析像を Fig. 10 に示 す。 3 種の添加剤 (チ才尿素 $0.0225 \mathrm{mmol} / \mathrm{L}$ ) を含む溶液 (a) では, 傾斜した繊維状の結晶とエピタキシャル成長型の結晶が混在した ものとなった。チオ尿素の濃度を $0.12 \mathrm{mmol} / \mathrm{L}$ と高くしても $(\mathrm{b})$ ， 電場配向繊維型とエピタキシャル成長型の結晶が混在した形と なったが，結晶粒が全体的に小さくなり，また双晶が多くなった。 ニカワ, チオ尿素, 塩化物イオンの 3 種類の添加剤を含む溶液に おいて $260 \mathrm{~A} / \mathrm{m}^{2} て ゙ ~ 48$ 時間電解を行った場合, 電析初期は, 結晶粒 径が微細となるが初期から最表面までほぼ全て $<110>$ 方向に優先 配向した電場配向繊維型の組織となることが報告されている7)。

(Fig. 11) しかし, 電析初期 $\left(200 \mathrm{~A} / \mathrm{m}^{2}, 42\right.$ 分間の電解) では, 本研 究の結果から分かるように, 全てが電場配向繊維型の組織となっ 


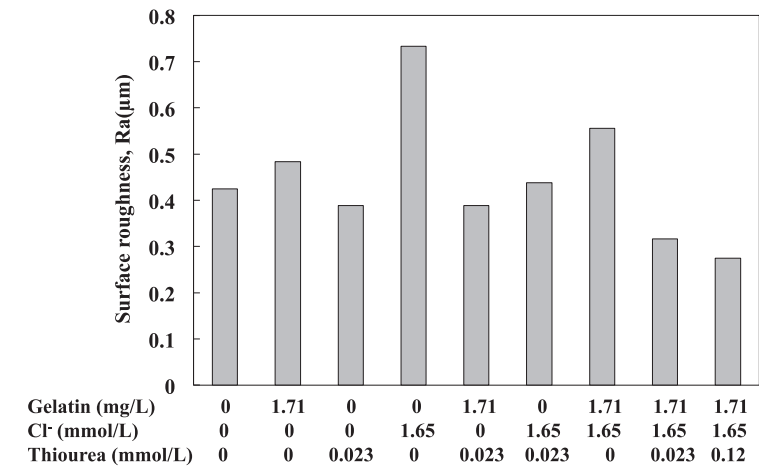

Fig.12 Surface roughness of $\mathrm{Cu}$ deposited for $42 \mathrm{~min}$ at $200 \mathrm{~A} / \mathrm{m}^{2}$ from a solution containing various additives.

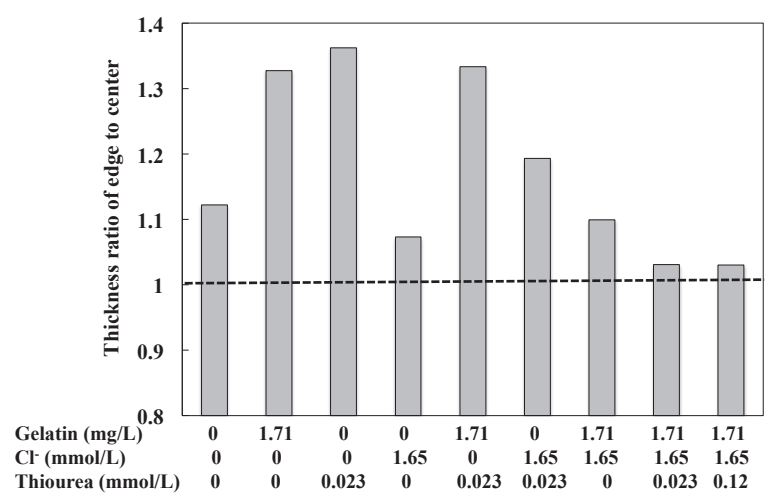

Fig.13 Thickness ratio of edge to center of $\mathrm{Cu}$ deposited for $42 \mathrm{~min}$ at $200 \mathrm{~A} / \mathrm{m}^{2}$ from a solution containing various additives.

ているわけではなく, 電析の途中で $\mathrm{Cu}$ の組織が変化することを 示している。

$3 \cdot 3$ 電析 $\mathrm{Cu}$ の表面粗度, 均一電着性に及ぼす添加剂の影響

Fig. 12 に各種の添加剤を含む $60^{\circ} \mathrm{C}$ の溶液から $200 \mathrm{~A} / \mathrm{m}^{2}$ にて 42 分間電解を行い, 得られた電析 $\mathrm{Cu}$ の表面粗度 $\mathrm{Ra}$ を示す。電 析 $\mathrm{Cu}$ の表面粗度は, ゼラチン, チオ尿素, 塩化物イオンの 3 種 類の添加剤を含む溶液において最も小さくなっており, 添加剤の 相乗効果が見られた。3 種類の添加剂を含む溶液の中でもチ才尿 素の濃度の高い方が粗度は小さくなった。個々の添加剤の影響を みると, チ才尿素は粗度を小さくし, 塩化物イオンは逆に粗度を 大きくした。チオ尿素 ${ }^{10-12)}$ は， $\mathrm{Ni}, \mathrm{Cu}$ 等の電気めっきにおける 光沢剤として使用されており ${ }^{13,14)}$, 原子レベルの平滑化作用が あることが報告されている ${ }^{14,15)}$ 。本研究における極微量の添加 においてもチ才尿素は粗度を下げる効果があり, その濃度が増加 する程, 平滑化効果は大きくなると考えられる。塩化物イオンは $<110>$ 優先方位の電場配向繊維型組織の形成を促進したが, 表面 粗度を増大させる作用が生じた。塩化物イオンとゼラチンの 2 種 を添加した場合も, 塩化物イオンの粗度を増加させる作用が働き, 粗度は高めとなった。ゼラチンのみを添加した場合は, 表面粗度 は低下寸ることが予想されたが，今回の添加条件では分極効果が 小さかったためか, 粗度はほとんど低下しなかった。

Fig. 13 に電析 $\mathrm{Cu}$ のエッジ部と中央部の膜厚の比率を示す。そ の比率が 1 に近いほど均一電着性が良いことを表す。電析 $\mathrm{Cu}$ の エッジ部と中央部の膜厚比は, ゼラチン, チ才尿素, 塩化物イオ ンの 3 種類の添加剤を含む溶液からの場合が最も 1 に近くなって おり, 添加剂の相乗効果が見られた。3 種類の添加剂を含む溶液 の中ではチ才尿素の濃度の影響は特に見られなかった。個々の添
加剂の影響をみると, 塩化物イオンは膜厚の比率を 1 に近づけ, チ才尿素は膜厚の比率を大きくした。即ち, 塩化物イオンは電 析 $\mathrm{Cu}$ の均一電着性を改善し，チ才尿素はそれを悪くすることを 表している。均一電着性に対する塩化物イオンとチオ尿素の効果 は, Fig. 12 に示した表面粗度に対する効果とは逆の傾向を示した。 塩化物イオンは $<110>$ 優先方位の電場配向繊維型組織の形成を 促進させる効果があり, その効果が均一電着性の改善に寄与して いる可能性がある。電析 $\mathrm{Cu}$ の表面粗度を小さくし, 均一電着性 を改善する上でのゼラチン, チオ尿素, 塩化物イオンの 3 種類の 添加剤の相乗効果のメカニズムについては不明な点が多く, 今後 の検討が必要である。ゼラチンのような高分子添加剤が可視光の 波長 $(400 \sim 600 \mathrm{~nm})$ よりも大きな領域の凹凸の平滑化作用があ るのに対して, チ才尿素のような光沢剤は, 先に述べたように原 子レベルの平滑化作用があることが報告されている ${ }^{14,15)}$ 。微量 添加のチオ尿素には銅電析の復極作用があり, 凹部での電析促進 による平滑化効果も期待される。本研究では, 塩化物イオンによ る $<110>$ 優先方位の電場配向繊維型組織の形成, ゼラチンの巨 視的なレベリング作用, チ才尿素の微視的な平滑化作用の相乗効 果により, 電析 $\mathrm{Cu}$ の表面粗度が小さくなり, 均一電着性が改善 されたと考えられる。

ところで, ULSI デバイスの微細配線には $\mathrm{Cu}$ ダマシンめっき が適用されている。ダマシンめっきには, $\mathrm{Cu}$ 電析を促進する $\mathrm{S}$ 系のビス (3-スルフォプロピル) ジスルフィド (SPS), 電析を抑制 するポリエチレングリコール (PEG) と塩化物イオンが添加され ている ${ }^{15)}$ 。SPS とチ才尿素は S 系の添加剤であり, PEG とゼラ チンはともに直鎖状の高分子添加剤であることから, $\mathrm{Cu}$ ダマシ ンめっきと本研究の $\mathrm{Cu}$ 電解精製では, 添加剤の構成は極めて類 似していると言える。今後, $\mathrm{Cu}$ ダマシンめっきとの関連性から $\mathrm{Cu}$ 電解精製における添加剤の作用機構を検討するのも興味深い。

\section{4. 結言}

$\mathrm{Cu}$ 電析の分極曲線および電析初期の $\mathrm{Cu}$ (膜厚 : 約 $18 \mu \mathrm{m}$ ) の表 面形態, 結晶組織, 表面粗度, 均一電着性に及ぼす添加剂の相 乗効果について調査し, 以下の結果を得た。 $60^{\circ} \mathrm{C}$ 電解液にゼラ チンと塩化物イオンを添加すると, $200 \mathrm{~A} / \mathrm{m}^{2}$ 以上の電流密度域で $\mathrm{Cu}$ の電析電位は大きく分極した。チ才尿素は $500 \sim 1000 \mathrm{~A} / \mathrm{m}^{2}$ の電流密度域で $\mathrm{Cu}$ の電析電位を復極させる効果があった。ゼラ チン, 塩化物イオン, チオ尿素の 3 種の添加剂を含む溶液では, $500 \mathrm{~A} / \mathrm{m}^{2}$ の電流密度で分極が認められた。チ才尿素には復極効果 があるが，ゼラチンと塩化物イオンには，分極の相乗効果があ り, その分極の相乗効果の方が勝ったためと考えられる。塩化物 イオンは, 電析 $\mathrm{Cu}$ を初期から $<110>$ 配向の電場配向繊維型にす る効果があることが分かった。しかし, ゼラチン, 塩化物イオン, チ才尿素の 3 種の添加剂を含む溶液からの電析初期の $\mathrm{Cu}$ には傾 斜した繊維状の結晶とエピタキシャル成長型の結晶が混在してい た。電析 $\mathrm{Cu}$ の表面粗度, 均一電着性は, ゼラチン, チオ尿素, 塩化物イオンの 3 種類の添加剤を含む溶液からの場合が最も改善 されており, 添加剤の相乗効果が見られた。チオ尿素には粗度を 小さくする効果があり, 塩化物イオンには均一電着性を向上させ る効果が認められた。

\section{References}

1) C.L. Mantell: Electrochemical Engineering, (McGraw-Hill Book Company, Inc., New York, NY, U.S.A., 1960) , pp.142-167, 185-192, 210-224.

2) Hitetsu Kinzoku Seiren, (Nippon Kinzoku Gakkai, Sendai, 1980), pp.228,241.

3) Denki Kagaku Binran, (Denki Kagaku Kyokai, Maruzen, Tokyo, 1985), pp.308-327.

4) H. Nakano, S. Oue, T. Ohgai, K. Izumi, T. Akiyama and H. Fukushima: Journal of MMIJ, 
119 (2003), 663-667.

5) H. Kuboyama, H. Nakano, S. Oue, H. Fukushima and S. Kobayashi: Journal of MMIJ, 125 (2009), 62-67.

6) H. Nakano, S. Oue, K. Aoya, H. Kuboyama ,H. Fukushima and S. Kobayashi: Journal of MMIJ, 123 (2007), 165-170.

7) H. Nakano, S. Oue, Y. Tsuyama, H. Kuboyama ,H. Fukushima, S. Kobayashi and K. Tomioka: Journal of MMIJ, 127 (2011), 662-666.

8) J. M. West, translated by T. Ishikawa and T. Shibata: Electrodeposition and Corrosion Process, $2^{\text {nd }}$ Edition, (Sangyo Tosho, Tokyo, 1977), pp.34-35.

9) H. H. Bauer, translated by R. Tamamushi and G. Satoh: Electrode Reactions, (Tokyo Kagaku Dojin, Tokyo, 1976), pp.76-78.
10) T. Mine, R. Tominaga and T. Seiyama: DENKI KAGAKU (presently Electrochemistry), 35 (1967), 472-477.

11) T. Seiyama, R. Tominaga, T. Mine and K. Kono: DENKI KAGAKU (presently Electrochemistry) ,35 (1967), 849-853.

12) M. Matsuoka and T. Hayashi: DENKI KAGAKU (presently Electrochemistry) , 42 (1974), 462-467.

13) M. Kawasaki and H. Enomoto: Mekki Kyohon, (Nikkan Kogyo Shinbunsya, Tokyo, 1988), pp.83-84.

14) S. Haruyama: Electrochemistry for Surface Engineer, (Maruzen, Tokyo, 2001) , p.152

15) Jisedai Mekki Gizyutsu, (Denki Mekki Kenkyukai, Nikkan Kogyo Shinbunsya, Tokyo, 2004), pp.7-12. 